\title{
Temporal Microbial Response to Wetting-Drying Cycles in Soils within and Outside the Influence of a Shrub in the Sahel
}

\author{
Sally Diatta1,2 (i), Sidy Diakhaté1,3, Hassna Founoune-Mboup ${ }^{1 *}$, Charlotte J. Alster ${ }^{4}$, Diégane Diouf², \\ Richard P. Dick5 ${ }^{5}$, Lydie Chapuis-Lardy ${ }^{6}$, Laurent Cournac ${ }^{6}$, Ndeye Yacine Badiane-Ndour ${ }^{1}$
}

${ }^{1}$ ISRA_LNRPV, Laboratoire National de Recherches sur les productions Végétales (LNRPV), Dakar, Senegal

${ }^{2}$ Université Cheikh Anta Diop (UCAD), Département Biologie Végétale, Laboratoire Commun de Microbiologie

IRD/ISRA/UCAD, Dakar, Senegal

${ }^{3}$ IRD, LMI IESOL, Centre IRD-ISRA, Dakar, Senegal

${ }^{4}$ Department of Ecology and Evolutionary Biology, University of California, Irvine, CA, USA

${ }^{5}$ School of Environment and Natural Resources, Ohio State University, Columbus, OH, USA

${ }^{6}$ IRD, Institut de Recherche pour le Développement, UMR Eco \& Sols, Montpellier, France

Email: *hassna.mboup@isra.sn

How to cite this paper: Diatta, S., Diakhaté, S., Founoune-Mboup, H., Alster, C.J., Diouf, D., Dick, R.P., Chapuis-Lardy, L., Cournac, L. and Badiane-Ndour, N.Y. (2019) Temporal Microbial Response to Wetting-Drying Cycles in Soils within and Outside the Influence of a Shrub in the Sahel. Open Journal of Soil Science, 9, 284-297. https://doi.org/10.4236/ojss.2019.912018

Received: November 23, 2019 Accepted: December 28, 2019 Published: December 31, 2019

Copyright $\odot 2019$ by author(s) and Scientific Research Publishing Inc. This work is licensed under the Creative Commons Attribution International License (CC BY 4.0).

http://creativecommons.org/licenses/by/4.0/

\begin{abstract}
Piliostigma reticulatum is a native woody shrub found in cropped fields in the Sahel and has been shown to increase crop productivity and soil quality. Frequently occurring drying and rewetting cycles (DRW) may alter the soil quality beneath these shrubs. We investigated the effect of DRW cycles on microbial community in soil beneath and outside the $P$. reticulatum canopy and the roles of this shrub in the adaptation of the microbial community to abiotic stress. Soils were incubated in a climate controlled chamber for 45 days, after exposure to 10 consecutive days of DRW cycles at $75 \%$ of water holding capacity (WHC). Basal respiration, $\beta$-glucosidase activity, microbial biomass carbon $\left(\mathrm{MB}_{\mathrm{C}}\right)$, and available nitrogen $\left(\mathrm{NH}_{4}^{+} ; \mathrm{NO}_{3}^{-}\right)$were measured at 2, 30, and 45 days after soil exposed to the DRW cycles. $\mathrm{MB}_{\mathrm{C}}$ increased significantly two days after the DRW cycles and was greater for soil beneath the shrub canopy compared with soil outside the shrub canopy. PCA analysis based on basal respiration, microbial biomass carbon, available nitrogen, and $\beta$-Glucosidase activity resulted in a tight clustering in the beneath shrub soil samples. Soils incubated for more than 30 days after DRW cycles had higher available nitrogen content than soils incubated for less than 30 days. Soil from beneath the shrub canopy significantly improved soil resilience based on $\beta$-glucosidase activity. Soil from beneath the shrub canopy also had higher nutrient levels and greater microbial activity even when subjected to DRW cycles, potentially improving the ability of crops to withstand in-season drought when they are adjacent to shrubs. The work should bring our scien-
\end{abstract}


tific community into a more comprehensive assessment of potential effects of a crop-shrub intercropping that may allow for increased crop yields in semi-arid ecosystems under drought conditions.

\section{Keywords}

Sub-Saharan Africa, Shrub-Based Cropping System, Climate Change, Wetting and Drying Cycles, Climate Chamber Experiment

\section{Introduction}

In Sub-Saharan Africa, perennial woody shrubs have been shown to significantly influence soil microbial communities in cropped fields of the semi-arid Sahel [1] [2] [3]. A regional meta-analysis reporting the effects of shrub presence in African agricultural fields found an overall positive effect on total soil carbon (i.e. $+20 \%$ to $75 \%)$, higher millet and sorghum yields $(+25$ to $+120 \%)$, and higher or equal cereal yields when cropped with shrub-based ramial wood (+30 to $+100 \%)$ [4]. Recent research has found that the shrub Piliostigma reticulatum, commonly found in Senegal and other parts of Sub-Saharan Africa, significantly promotes crop growth and improves soil quality [5] [6] [7].

In cropped fields, these shrub species are ecologically similar to woody species in unmanaged semi-arid environments where they are known to create "islands of fertility" through increased litter inputs and root activity/turnover [8]. This effect is now more broadly termed "resource islands" because of the array of beneficial services they provide, including improved water distribution [9], nutrient abundance and availability, microbial habitat, and micro-environmental properties (temperature, humidity) [3] [6] [10]. Furthermore, P. reticulatum is known to perform hydraulic lift [9] which improves soil moisture by moving water from areas of high water potential in the wet sub soil to areas of low water potential at the surface. Previous work has shown that soil around the shrubs maintains microbial diversity and activity; and drives nutrient mineralization and decomposition through the long dry season [2] [10] [11]. Interactions between native shrubs and soil biota improve plant growth and soil microbial activity through increased water and nutrient availability [9] [12] [13]. These interactions are necessary for primary production of associated crops and for maintaining the long-term functioning in these semi-arid agroecosystems [14]. Soil microbial communities contribute to the stability of these important agroecosystems as key drivers in sustainable crop production [15].

The resistance and resilience of this telluric microbial community may be controlled by multiple soil properties such as microbial biomass, microbial community diversity, $\mathrm{pH}$, nutrient availability, soil organic matter, and soil texture [16] [17]. However, this resistance and resilience can be measured by the response to irregular and extreme water stresses on soil microorganisms [18] [19] [20] by imposing drying/rewetting (DRW) cycling events [21]. This soil 
moisture fluctuation and elevation of temperature will increase with climate change in the Sahel and is of particular concern when this stress event occurs during the growing season [22]. Soils that have conditioned microbial communities could more rapidly respond to perform soil ecosystem services to assist crops through in-season drought. Abrupt changes in water potential leads to either microbial death or microbial survival by quick release of accumulated solutes [23].

To our knowledge, there is very little information on the legacy effects of shrubs impact on microbial responses to DRW disturbances, particularly, in Sub-Saharan Africa. This research builds on Bright [5] and Diakhate [1] findings, which suggest that long-term shrub management can buffer against impacts of climate change and that the soil microbial communities can adapt to water stress. To determine the potential of a long-term shrub presence in buffering impacts of severe disturbance on soil microbial activity, a laboratory experiment was conducted under various temperature and humidity regimes. The objective was to investigate the resistance and resilience of microbial communities to DRW cycling stress by measuring microbial biomass and activity (enzymatic and respiration) response on soils within and outside the influence of shrubs.

\section{Material and Methods}

\subsection{Site Description and Soil Sampling}

The sampling site was located at Keur Ndary Ndiaye near Nioro (Southern region of the Senegalese Peanut Basin). The climate is semi-arid with an annual precipitation of $600-800 \mathrm{~mm}$ rainfall per year distributed from July to September, and a mean annual temperature ranging from $20^{\circ} \mathrm{C}$ in December-January to $35.7^{\circ} \mathrm{C}$ in April-June [24]. The soil is a fine-sandy, mixed Haplic Ferric Lixisol, locally called Deck-Dior [24]. The dominant native shrub species at the site is Piliostigma reticulatum (DC.) Hochst (Caesalpinioideae), with a stand of about 185 shrubs per hectare [25]. The soil was sampled both beneath the root system of the shrub and outside of the shrub influence $(\sim 10 \mathrm{~m})$ at a $0-10 \mathrm{~cm}$ depth. The soils were sieved to $2 \mathrm{~mm}$ to be used for experiment.

\subsection{Experimental Design}

We set up a microcosm-based incubation experiment in a climatic chamber (model KBWF 240, Binder GmbH). Both topsoil samples collected beneath and outside of the shrub influence were placed in microcosms (100 g per pot) and wetted to $75 \%$ of field capacity. The relative humidity in the chamber was maintained at $65 \% \pm 5 \%$ throughout the experiment. All microcosms with soil were pre-incubated at $28^{\circ} \mathrm{C}$ in the dark for 2 weeks in order to standardize initial conditions and reactivate the soil microbial communities [26]. After pre-incubation three replicates were sampled, corresponding to the control, at day zero.

Soils samples were separated in two series: 1) 24 microcosms were maintained 
at $28^{\circ} \mathrm{C}$ and $75 \%$ field capacity during the entirety of the experiment serving as control treatment, and 2) 24 microcosms were subjected to repeated DRW cycles as DRW treatment. Ten DRW cycles were implemented during the experimental period of 70 days. Each cycle contained two periods lasting 24 hours: 10 hours of drying at $55^{\circ} \mathrm{C}$, followed by 14 hours of incubation at $28^{\circ} \mathrm{C}$ after rewetting. At the end of the ten DRW cycles, the soil moisture was held constant at $75 \%$ field capacity and at $28^{\circ} \mathrm{C}$ for an additional 45 -day period with weekly adjustments of soil water content. To determine the effect of DRW cycles on microbial communities, six replicates (three replicates for the DRW treatment and three replicates for the control treatment) were destructively sampled at 2, 30 and 45 days after the end of the DRW cycles for soil analyses.

\subsection{Soil Analyses}

Microbial biomass $\mathrm{C}, \mathrm{N}$ mineral , basal respiration, and $\beta$-glucosidase activity were performed on days $0,2,30$ and 45 from control treatment (composed of microcosms that were maintained at $28^{\circ} \mathrm{C}$ and $75 \%$ field capacity during the entirety of the experiment) and the DRW treatment (subjected to the DRW cycles).

\subsubsection{Microbial Biomass}

Microbial biomass of carbon was determined according to the fumigation extraction method described by Amato and Ladd [27] with three replicates per soil sample (including an additional three serving as controls). Soils were fumigated with chloroform vapors to lyse the microbial cells and extracted with $2 \mathrm{M} \mathrm{KCl}$ after 10 days. Measurements of ninhydrin-reactive $\mathrm{N}$ released and extracted from the fumigated and non-fumigated soils provide a useful assay of biomass $\mathrm{N}$. The carbon was calculated from the chloroform labile $\mathrm{C}$ which was multiplied by a factor of 21 to estimate microbial biomass $\mathrm{C}$.

\subsubsection{N Mineral}

Available $\mathrm{N}\left(\mathrm{NH}_{4}^{+}+\mathrm{NO}_{3}^{-}\right)$content was determined colorimetrically in $\mathrm{KCl} 1$ $\mathrm{M}$ extracts by flow injection analysis according to Bremner methods [28].

\subsubsection{Basal Respiration}

Basal respiration was estimated by quantifying $\mathrm{CO}_{2}$ evolution from soils. A $30 \mathrm{~g}$ aliquot of each soil sample was filled in $50 \mathrm{ml}$ glass jars and sealed with air-tight lids equipped with rubber septa to allow gas sampling of the headspace. $\mathrm{CO}_{2}$ concentrations in the headspace were measured at each sampling date using a micro chromatograph (Varian, Inc.) and expressed as $\mu \mathrm{g} \cdot \mathrm{C}-\mathrm{CO}_{2} \cdot \mathrm{g} \cdot \mathrm{soil}^{-1} \cdot \mathrm{h}^{-1}$. We then calculated the metabolic quotient $\left(\mathrm{qCO}_{2}\right)$ as the ratio between the basal respiration and microbial biomass carbon.

\subsection{4. $\beta$-Glucosidase Enzyme Activity}

$\beta$-Glucosidase activity was determined according to a method adapted from Hayano [29]. $\beta$-glucosidase activity was selected since it detects changes in soil 
management within relatively short time periods ( $1-3$ years) and is relatively stable within season [30] [31]. Briefly, for each sample, $100 \mathrm{mg}$ of soil was incubated for $2 \mathrm{~h}$ at $37^{\circ} \mathrm{C}$, with $100 \mu \mathrm{l}$ of para-nitrophenyl $\beta$ D-Glucopyranoside (5 $\mathrm{mM}$; Sigma), and $400 \mu \mathrm{l}$ of a citrate phosphate buffer [32] at $\mathrm{pH} 5.8$. After the incubation, the reaction was stopped with $3 \mathrm{ml}$ of $0.2 \% \mathrm{Na}_{2} \mathrm{CO}_{3}(\mathrm{w} / \mathrm{v}) . \mathrm{Pa}$ ra-Nitrophenol (PNP) was released as the product of the enzymatic reaction, measured at $\lambda=400 \mathrm{~nm}$ using a spectrophotometer and results were expressed as $\mu \mathrm{g} \cdot \mathrm{PNP} \cdot \mathrm{g}^{-1} \cdot \mathrm{soil}^{-\mathrm{h}^{-1}}$.

\subsection{Statistical Analysis}

A one-way ANOVA was used to determine whether differences existed between treatments (beneath and outside the shrub canopy) at the different days measured using XLSTATSoftware. Statistical tests were performed to highlight the effects of disturbance on the soil respiration, total microbial biomass, and enzymatic activities. A Fisher (LSD) test was used to compare means $(P<0.05)$. Multivariate analysis using Principal Components Analysis (PCA) was performed with the combination of all data using the PC-ORD software (MjM Software Design, Gleneden Beach, OR) [33].

\section{Results}

\subsection{Effects of DRW on Soil Available N}

Available nitrogen was significantly higher 30 days after DWR cycles in both soils, beneath and outside of the shrub's influence (Figure $1 ; P<0.05$ ). Forty Five (45) days after DRW cycles, no differences were observed in available $\mathrm{N}$ content in the beneath shrub treatments however soils collected outside of the shrub still showed significant differences in response to DRW cycles $(P<0.05)$.

\subsection{Effects of DRW on Basal Respiration}

There was a significant effect of DRW cycles on basal respiration (Figure 2; $P<$ $0.05)$. Basal respiration was consistently lower in stressed soils compared to the
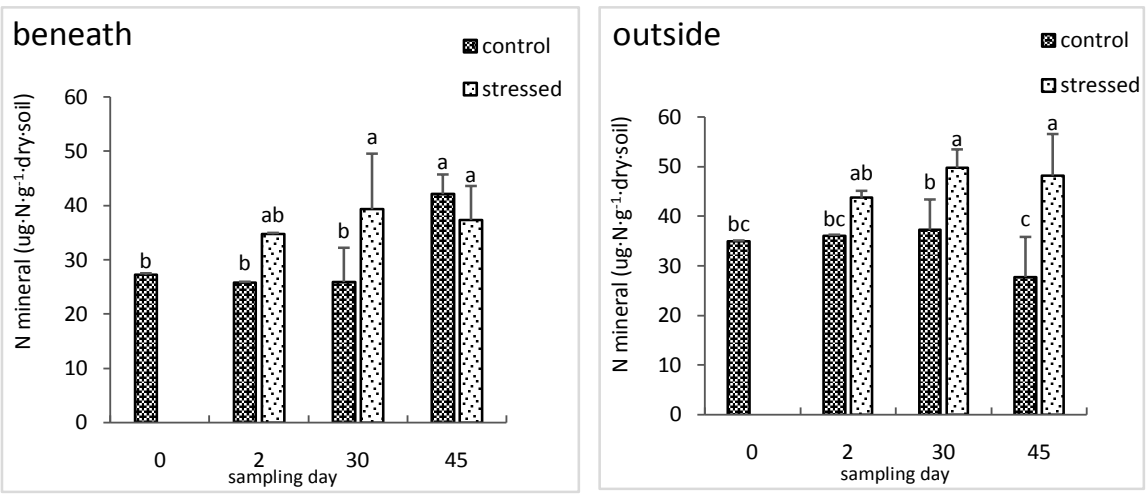

Figure 1. Effect of the DRW cycles on available $\mathrm{N}$ from soil collected beneath and outside of shrub influence $(n=4)$. Error bars represent one standard deviation. Letters denote significant differences among treatment means (Fisher's test, $P<0.05$ ). 


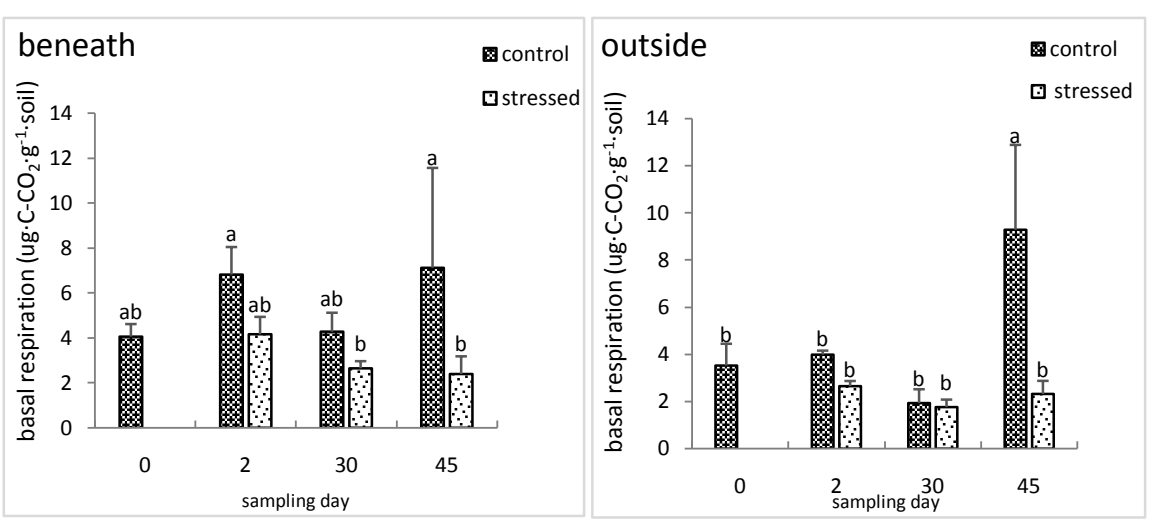

Figure 2. Effect of DRW cycles on basal respiration from soil collected beneath and outside of shrub influence $(\mathrm{n}=4)$. Error bars represent one standard deviation. Letters denote significant differences among treatment means (Fisher's test, $P<0.05$ ).

control over time. No change was found 2 and 30 days after disturbance, however 45 days after DRW cycles basal respiration was more than 3 times higher in control soils than in stressed soils (Figure 2).

\subsection{Effects of DRW on Soil Microbial Biomass Carbon}

Soil microbial biomass carbon was significantly affected 2 days after DRW cycles (Figure 3; $P<0.05$ ). Microbial biomass carbon was greater in stressed soils than control soils regardless of the sampling location (beneath shrub or outside of shrub influence). The highest value of microbial biomass carbon in this study was recorded in the stressed soil 2 days after DRW cycles (56.33 $\mu \mathrm{g} \cdot \mathrm{PNP} \cdot \mathrm{g}^{-1} \cdot \mathrm{sol} \cdot \mathrm{h}^{-1}$ ) and significantly decreased 30 and 45 days after disturbance in both the beneath shrub and outside of shrub soil treatments.

\subsection{Effects of DRW on the Metabolic Quotient}

Despite significant differences in basal respiration and microbial biomass carbon, the metabolic quotient $\left(\mathrm{qCO}_{2}\right)$ was neither affected by shrub influence nor by DRW cycles (Figure 4; $P>0.05$ ). However, we did find an increase in the metabolic quotient in the control soil collected from outside the shrub at day 45 $(P<0.05)$.

\subsection{Effects of DRW on $\beta$-Glucosidase Activity}

Enzyme activity was greater over time in the beneath shrub treatment compared to the outside of shrub treatment (Figure 5). DRW cycles significantly decreased $\beta$-Glucosidase activity $(P<0.0001)$ in both beneath and outside of shrub soils. In the beneath shrub soils, $\beta$-glucosidase activity decreased significantly from day 0 to day 2 , but did not change between day 2 and day 30. In the outside of shrub soils there was a significant difference in $\beta$-Glucosidase activity between day 0 and days 2 and $30(P<0.0001)$, but no change was observed between day 30 and day 45. 


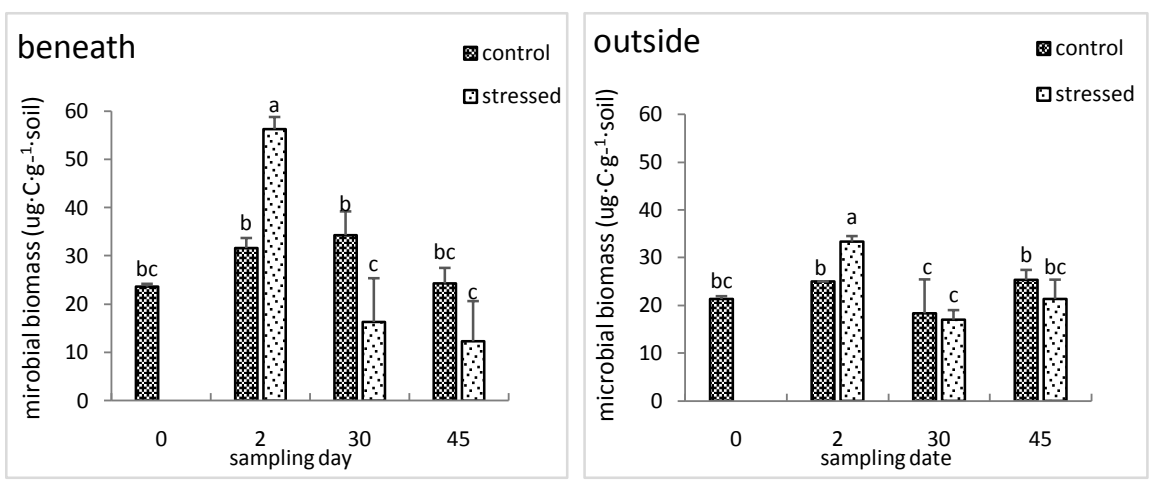

Figure 3. Effect of DRW cycles on microbial biomass carbon from soil collected beneath and outside shrub influence $(n=4)$. Error bars represent one standard deviation. Letters denote significant differences among treatment means (Fisher's test, $P<0.05$ ).

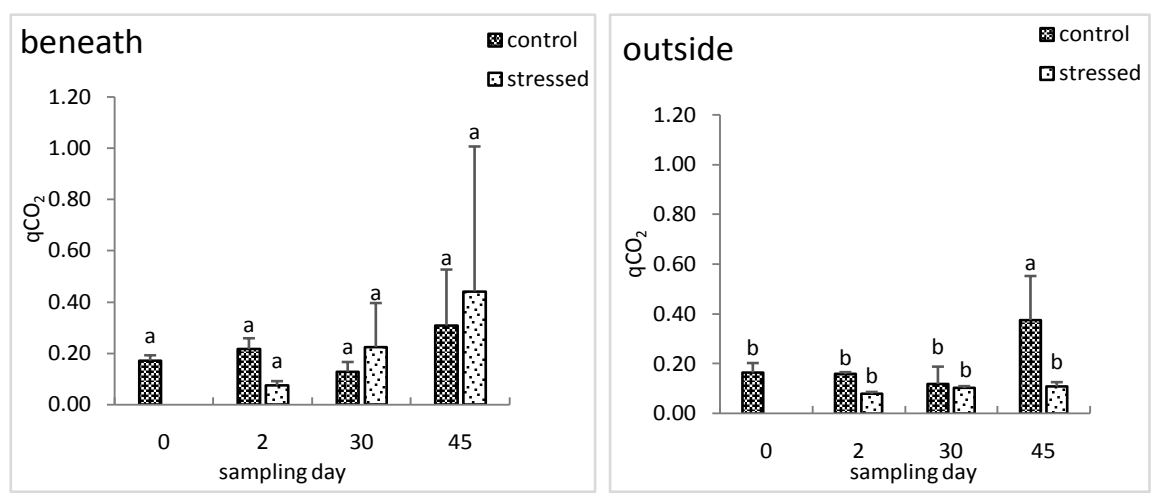

Figure 4. Effect of DRW cycles on the metabolic quotient from soil collected beneath and outside shrub influence $(\mathrm{n}=4)$. Error bars represent one standard deviation. Letters denote significant differences among treatment means (Fisher's test, $P<0.05$ ).
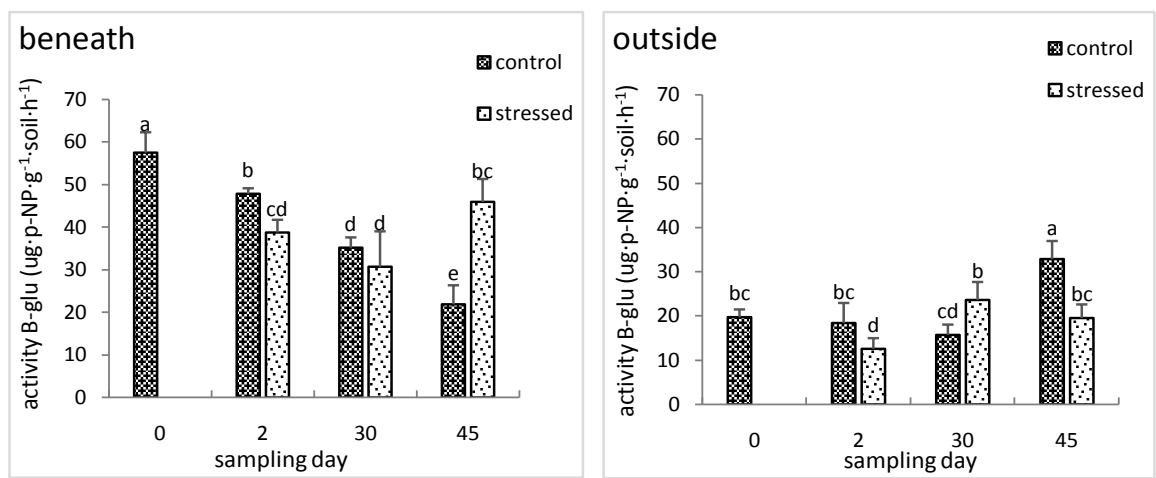

Figure 5. Effect of DRW cycles on $\beta$-glucosidase activity from soil collected beneath and outside shrub influence $(\mathrm{n}=4)$. Error bars represent one standard deviation. Letters denote significant differences among treatment means (Fisher's test, $P<0.05$ ).

\section{Discussion}

\subsection{Microbial Response to DRW Cycles}

This study compared the response of soil microbial communities subjected to DRW cycles on soils collected from beneath and outside of shrub canopies in the 
Sahel. The microbial parameters ( $\beta$-Glucosidase and basal respiration) were different between soil collected beneath and outside the influence of shrubs. PCA analysis showed that available nitrogen was related to the response of soil microbial activities under DRW cycles over time in both soil treatments (Figure 6(a)). Overall, soils collected from beneath the shrub responded negatively to the disturbance from the DRW cycles, except for available nitrogen. Similar observations were previously reported a negative correlation between imposed water stress and basal respiration [1]. The decreased rates of basal respiration were more noticeable in soils collected outside the shrub canopy, supporting the concept that these shrubs act as "resource islands" [12] and buffer against soil disturbance [1] [5]. It is also possible that increased organic matter availability in the soils beneath the shrub canopy influenced respiration upon rewetting [34].

Despite strong differences in basal respiration rates, our results demonstrate that $\mathrm{qCO}_{2}$ was not an important indicator of DRW cycles in this study. This may be related to the fact that communities inhabiting tropical sandy soils are frequently exposed to drought conditions in their natural environment and are already adapted to this type of stress, suggesting that this ecophysiological indicator was not sensitive to this type of disturbance. This could be due to the way $\mathrm{qCO}_{2}$ is calculated which is essentially the respiration rate to biomass ratio. So in two treatment comparison, even if one has lower respiration but at the same time biomass goes down proportionately, the $\mathrm{qCO}_{2}$ stays the same as the other treatment even though there were significant effects on respiration and biomass.

Microbial biomass was strongly influenced by the DRW cycles in this study, with soil microbial biomass increasing in stressed soils immediately following disturbance and decreasing over time. These results are supported by previous studies showing microbial biomass increasing after rewetting dry soils [35] [36]. Fierer and Schimel [35] inferred that rapid microbial growth from an increase in organic matter availability and the subsequent persistence of a semi-dormant state contributed to the increase of microbial biomass after DRW cycle, while Zhang [36] attributed this increase to the adjustment of the soil microbial community. In days 30 and 45 following DWR, microbial biomass dropped significantly and reached the same level before DRW cycles, suggesting a resiliency of the microbial communities in soils from beneath the shrub canopies (Figure 3 ).

Soil enzyme activities had similar treatment effects to what is described above. Soil enzyme activities are attractive as soil quality indicators because they are sensitive to soil management and relatively simple and cost effective [31]. Not surprisingly, this study found that year-round shrub management resulted in greater $\beta$-glucosidase activity compared to soil collected from outside the shrub area, except for the soils incubated for 45 days (Figure 5), which is consistent with previous studies [1] [10] [11]. However, decreases in $\beta$-glucosidase activity after DRW cycles, followed by a subsequent increase back to baseline levels, further suggests greater resiliency of the soil microbial communities collected from beneath the shrub canopy. These findings are in agreement with previous 

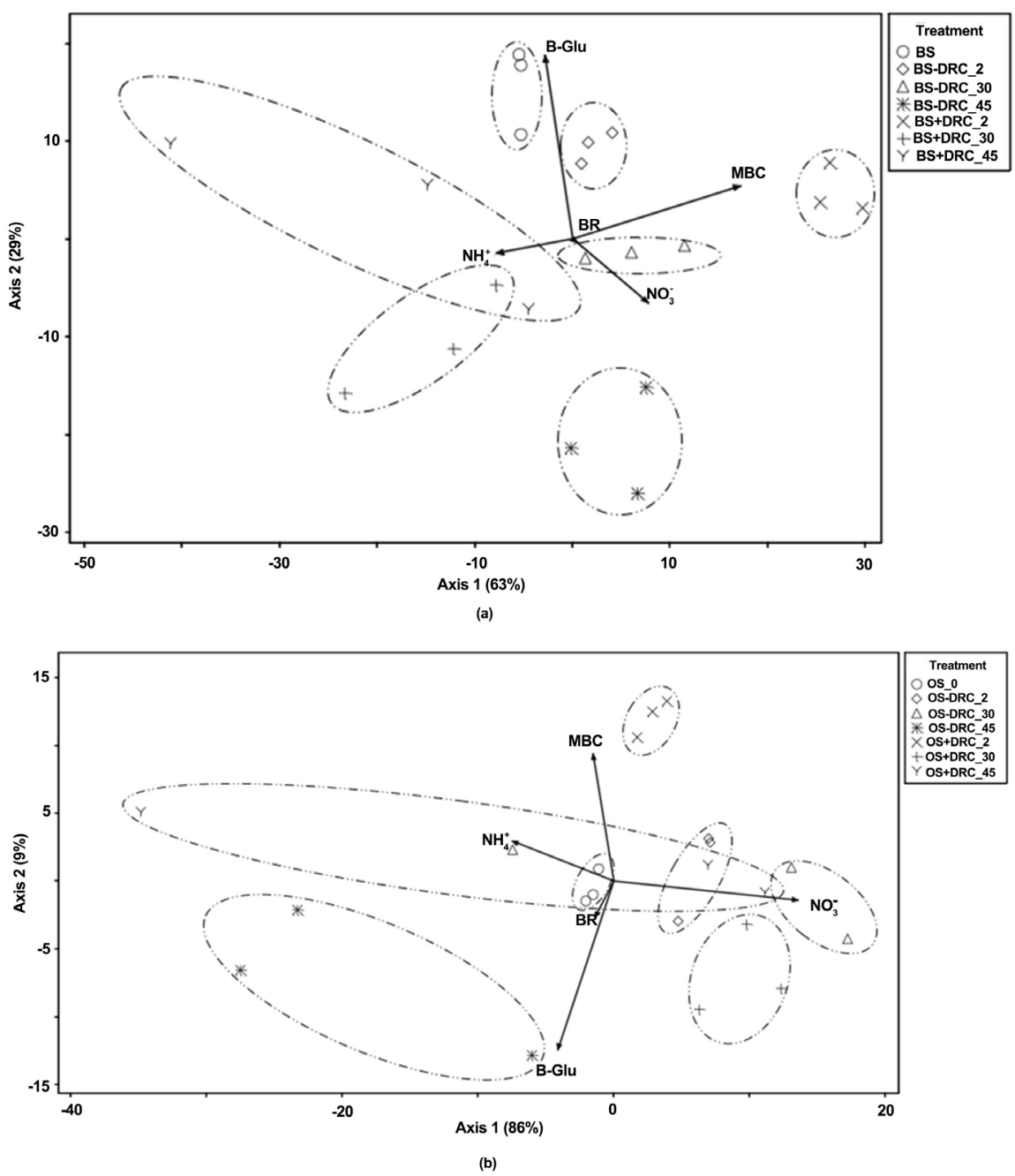

Figure 6. Ordination plot of Principal Component Analysis generated for chemical and microbiological soil parameters. (a) Beneath shrub (BS) soils with and without DRC (Drying and Rewetting Cycles) for each sampling date (0,2, 30 and 45 day after DRC), showing a clear discrimination between treatments. (b) Outside of shrub (OS) soils with and without DRW cycles for each sampling date $(0,2,30$ and 45 day after DRC), showing a less clear discrimination among the different treatments.

observations that microbial activities are able to completely recover after transient stress [37].

\subsection{Shrub Effects on Microbial Activities under DRW Effects}

The analyses revealed that soils collected from beneath the shrub had less differences in their microbial and biochemical parameters than soils collected outside the shrub area when subjected to DRW cycles (Figure 6). There is now considerable evidence that the shrub $P$. reticulatum increases water availability by performing hydraulic redistribution [13], has higher levels of microbial activity and diversity [1] [2] [10], and suppresses plant parasitic nematodes [24] [38]. Drying and rewetting cycles led to an increase in soil microbial biomass and $\beta$-glucosidase activity after 2 days of incubation. After 30 days of incubation, 
there were positive relationships between microbial properties and available $\mathrm{N}$ (Figure 6).

The mechanisms for the positive impact of $P$. reticulatum in soils on microbial responses to DRW may be due to improved microclimatic conditions, increased nutrient mineralization rate, and increased organic matter, nutrients, and fine soil particles under its canopy [12]. Conversely, a high level of functional redundancy within the soil microbial community may buffer against the adverse effect of DRW [15]. The role of microbial diversity in soil resilience is not simply linked to the absolute number of species present but is related to the functional traits of those species [15]. Interaction between these species significantly increases both resistance and resilience against disturbance because it acts to buffer against extinctions [39]. The findings of the present study support the hypothesis of the role of perennial shrubs as "resource islands" and moderators of abiotic perturbation (e.g., as a source of water and soil nutrients) that affect microbial activity of soils.

\subsection{Study Limitations and Considerations for Future Work}

Although we investigated the effects of drying and rewetting disturbance on soil chemical and microbiological parameters in a semi-arid soil affected by a long-term shrub management system, this study was limited by several uncertainties. The magnitude of DRW cycles and the duration of the experiment could be extended to learn more about the disturbance effect. Future research should attempt to increase the effects of intensity and duration of DRW events on the stability of microbial communities under $P$. reticulatum management. Given the fact that microbial communities under large shrubs have higher species richness, greater biomass, and more perennial species than communities under small shrubs, it could prove helpful to establish the link between changes in how resistance and resilience in soil microbial communities can be impacted by shrub age. Furthermore, detailed studies are needed to directly link hydraulic redistribution of water by shrubs with support of microorganisms in the shrub root zone under DRW stress in the field.

\section{Conclusions}

This study contributes to the understanding of shrub management legacies and its positive effect on soil microbial stability. Our results showed strong variation in soil available nitrogen content and microbial activity in response to DRW cycles. Microbial biomass carbon and $\beta$-glucosidase activity generally increased after DRW cycles in soils collected under shrub canopies while basal soil respiration rates decreased with DRW cycles irrespective of the soil sampling locations and time of incubation. The levels of microbial biomass carbon, basal respiration, and enzyme activities were more strongly influenced by the DRW cycles than shrub management. Nonetheless, our findings suggest that shrub influence in a semi-arid zone is a major driver controlling microbial responses and does 
reduce microbial stress to DRW. This study contributes to the understanding of factors influencing soil microbial activities over time under shrub management when they are affected by extreme climate events.

\section{Acknowledgements}

This work was funded by the by the USAID PEER Program under grant agreement: \#AID-OAA-A-11-00012 in collaboration with the US National Science Foundation. We would like to thank the numerous individuals who helped establish this study. We would like to thank especially Dr. Roger BAYALA and Dr. Ibrahima DIÉDHIOU for assistance in collecting soils. We are grateful to Moustapha SANE, Lamine SAGNA and the late Amadou DIOP for lab technical assistance at the LMI IESOL analytical platform.

\section{Conflicts of Interest}

The authors declare no conflicts of interest regarding the publication of this paper.

\section{References}

[1] Diakhaté, S., Gueye, M., Chevallier, T., Diallo, N.H., Assigbetse, K., Abadie, J., Diouf, M., Masse, D., Sembene, P.M., Badiane-Ndour, N.Y., Dick, R.P. and Chapuis-Lardy, L. (2016) Soil Microbial Functional Capacity and Diversity in a Millet-Shrub Intercropping System of Semi-Arid Senegal. Journal of Arid Environment, 129, 71-79. https://doi.org/10.1016/j.jaridenv.2016.01.010

[2] Debenport, S.J., Assigbetse, K., Bayala, R., Chapuis-Lardy, L., Dick, R.P. and McSpadden Gardener, B.B. (2015) Association of Shifting Populations in the Root Zone Microbiome of Millet with Enhanced Crop Productivity in the Sahel Region (Africa). Applied and Environmental Microbiology, 81, 2841-2851. https://doi.org/10.1128/AEM.04122-14

[3] Diedhiou, S., Dossa, E.L., Badiane, A.N., Diedhiou, I., Sene, M. and Dick, R.P. (2009) Decomposition and Spatial Microbial Heterogeneity Associated with Native Shrubs in Soils of Agroecosystems in Semi-Arid Senegal. Pedobiologia, 52, 273-286. https://doi.org/10.1016/j.pedobi.2008.11.002

[4] Felix, G.F., Scholberg, J.M.S., Clermont-Dauphin, C., Cournac, L. and Tittonel, P. (2018) Enhancing Agroecosystem Productivity with Woody Perennials in Semi-Arid West Africa. A Meta-Analysis. Agronomy for Sustainable Development, 38, 57. https://doi.org/10.1007/s13593-018-0533-3

[5] Bright, M.B.H., Diedhiou, I., Bayala, R., Assigbetse, K., Chapuis-Lardy, L., Ndour, Y. and Dick, R.P. (2017) Long-Term Piliostigma reticulatum Intercropping in the Sahel: Crop Productivity, Carbon Sequestration, Nutrient Cycling, and Soil Quality. Agriculture Ecosystems and Environment, 242, 9-22. https://doi.org/10.1016/j.agee.2017.03.007

[6] Dossa, E.L., Khouma, M., Diedhiou, I., Sene, M., Kizito, F., Badiane, A.N., Samba, S.A.N. and Dick, R.P. (2009) Carbon, Nitrogen and Phosphorus Mineralization Potential of Semi-Arid Sahelian Soils Amended with Native Shrub Residues. Geoderma, 148, 251-260. https://doi.org/10.1016/j.geoderma.2008.10.009

[7] Lufafa, A., Diedhiou, I., Ndiaye, A.S., Sene, M., Kizito, F., Dick, R.P. and Noller, J.S. 
(2009) Allometric Relationships and Peak-Season Community Biomass Stocks of Native Shrubs in Senegal's Peanut Basin. Journal of Arid Environment, 73, 260-266. https://doi.org/10.1016/j.jaridenv.2008.09.020

[8] Ridolfi, L., Laio, F. and D’Odorico, P. (2008) Fertility Island Formation and Evolution in Dryland Ecosystems. Ecology and Society, 13, 5.

https://doi.org/10.5751/ES-02302-130105

[9] Kizito, F., Dragila, M.I., Sène, M., Brooks, J.R., Meinzer, F.C., Diedhiou, I., Diouf, M., Lufafa, A., Dick, R.P., Selker, J. and Cuenca, R. (2013) Hydraulic Redistribution by Two Semi-Arid Shrub Species: Implications for Sahelian Agro-Ecosystems. Journal of Arid Environment, 83, 69-77. https://doi.org/10.1016/j.jaridenv.2012.03.010

[10] Hernandez, R., Debenport, S.J., Leewi, M.C., Ndoye, F., Nkenmogne, I.E., Soumare, A., Thuita, M., Gueye, M., Miambi, E., Chapuis-Lardy, L., Diedhiou, I. and Dick, R.P. (2015) The Native Shrub, Pilostigma reticulatum, as an Ecological "Resource Island" for Mango Trees in the Sahel. Agriculture Ecosystems and Environment, 204, 51-61. https://doi.org/10.1016/j.agee.2015.02.009

[11] Diedhiou-Sall, S., Dossa, E.L., Diedhiou, I., Badiane, A.N., Assigbetse, K.B., Samba, S.A.N., Khouma, M., Sene, M. and Dick, R.P. (2013) Microbiology and Macrofaunal Activity in Soil Beneath Shrub Canopies during Residue Decomposition in Agroecosystems of the Sahel. Soil Science Society of America Journal, 77, 501-511. https://doi.org/10.2136/sssaj2012.0284

[12] Dossa, E.L., Baham, J., Khouma, M., Sene, M., Kizito, F. and Dick, R.P. (2008) Phosphorus Sorption and Desorption in Semiarid Soils of Senegal Amended with Native Shrub Residues. Soil Science, 173, 669-682. https://doi.org/10.1097/SS.0b013e3181893999

[13] Bogie, N.A., Bayala, R., Diedhiou, I., Conklin, M.H., Fogel, M., Dick, R.P. and Ghezzehei, T.A. (2018) Hydraulic Redistribution by Native Sahelian Shrubs: Bioirrigation to Resist in-Season Drought. Frontiers in Environmental Science, 6, 98. https://doi.org/10.3389/fenvs.2018.00098

[14] Dossa, E.L., Diedhiou, I., Khouma, M., Sene, M., Badiane, A.N., Samba, S.A.N., Assigbetse, K., Sall, S., Lufafa, A., Kizito, F., Dick, R.P. and Saxena, J. (2013) Crop Productivity and Nutrient Dynamics in a Shrub-Based Farming System of the Sahel. Agronomy Journal, 105, 1237-1246. https://doi.org/10.2134/agronj2012.0432

[15] Griffiths, B.S. and Philippot, L. (2013) Insights into the Resistance and Resilience of the Soil Microbial Community. Microbiology Reviews, 37, 112-129.

https://doi.org/10.1111/j.1574-6976.2012.00343.x

[16] Orwin, K.H., Wardle, D.A. and Greenfield, L.G. (2006) Context-Dependent Changes in the Resistance and Resilience of Soil Microbes to an Experimental Disturbance for Three Primary Plant Chronosequences. Oikos, 1, 196-208. https://doi.org/10.1111/j.0030-1299.2006.13813.x

[17] Royer-Tardif, S., Bradley, R.L. and Parsons, W.F.J. (2010) Evidence that Plant Diversity and Site Productivity Confer Stability to Forest Floor Microbial Biomass. Soil Biology and Biochemistry, 42, 813-821. https://doi.org/10.1016/j.soilbio.2010.01.018

[18] Orwin, K.H. and Wardle, D.A. (2004) New Indices for Quantifying the Resistance and Resilience of Soil Biota to Exogenous Disturbances. Soil Biology and Biochemistry, 36, 1907-1912. https://doi.org/10.1016/j.soilbio.2004.04.036

[19] Borken, W. and Matzner, E. (2009) Reappraisal of Drying and Wetting Effects on C and N Mineralization and Fluxes in Soils. Global Change Biology, 15, 808-824. 
https://doi.org/10.1111/j.1365-2486.2008.01681.x

[20] Yu, Z., Wang, G. and Marschner, P. (2014) Drying and Rewetting-Effect of Frequency of Cycles and Length of Moist Period on Soil Respiration and Microbial Biomass. European Journal of Soil Biology, 62, 132-137.

https://doi.org/10.1016/j.ejsobi.2014.03.007

[21] Ouyang, Y. and Li, X. (2013) Recent Research Progress on Soil Microbial Responses to Drying-Rewetting Cycles. Acta Ecologica Sinica, 33, 1-6. https://doi.org/10.1016/j.chnaes.2012.12.001

[22] Bathiany, S., Dakos, V., Scheffer, M. and Lenton, T.M. (2018) Climate Models Predict Increasing Temperature Variability in Poor Countries. Sciences Advance, 4, eaar5809. https://doi.org/10.1126/sciadv.aar5809

[23] Shi, A. and Marschner, P. (2014) Drying and Rewetting Frequency Influences Cumulative Respiration and Its Distribution over Time in Two Soils with Contrasting Management. Soil Biology and Biochemistry, 72, 172-179. https://doi.org/10.1016/j.soilbio.2014.02.001

[24] Diakhate, S., Villenave, C., Diallo, N.H., Ba, A.O., Djigal, D., Masse, D., Sembene, P.M. and Chapuis, L.L. (2013) The Influence of a Shrub-Based Intercropping System on the Soil Nematofauna When Growing Millet in Senegal. European Journal of Soil Biology, 57, 37-41. https://doi.org/10.1016/j.ejsobi.2013.04.003

[25] Lufafa, A., Diedhiou, I., Samba, S.A.N., Sene, M., Khouma, M., Kizito, F., Dick, R.P., Dossa, E. and Noller, J.S. (2008) Carbon Stocks and Patterns in Native Shrub Communities of Senegal's Peanut Basin. Geoderma, 146, 75-82. https://doi.org/10.1016/j.geoderma.2008.05.024

[26] Amato, M. and Ladd, J.N. (1988) Assay for Microbial Biomass Based on Ninhydrin-Reactive Nitrogen Extracts from Fumigated Soil. Soil Biology and Biochemistry, 20, 107-114. https://doi.org/10.1016/0038-0717(88)90134-4

[27] Zhao, B., Chen, J., Zhang, J. and Qin, S. (2010) Soil Microbial Biomass and Activity Response to Repeated Drying-Rewetting Cycles along a Soil Fertility Gradient Modified by Long-Term Fertilization Management Practices. Geoderma, 160, 218-224. https://doi.org/10.1016/j.geoderma.2010.09.024

[28] Bremner, J.M. (1965) Inorganic Forms of Nitrogen. In: Black, C.A., Ed., Methods of Soil Analysis, Part 2 Agronomy Monograph, American Society of Agronomy, Madison, WI, 1179-1237.

[29] Hayano, K. (1973) A Method for Determination of $B$-Glucosidase Activity in Soil. Soil Science and Plant Nutrition, 19, 103-108. https://doi.org/10.1080/00380768.1973.10432524

[30] Bandick, A.K. and Dick, R.P. (1999) Field Management Effects on Soil Enzyme Activities. Soil Biology and Biochemistry, 311, 47-1479. https://doi.org/10.1016/S0038-0717(99)00051-6

[31] Ndiaye, E., Sandeno, J.M., McGrath, D. and Dick, R.P. (2000) Integrative Biological Indicators for Detecting Change in Soil Quality. American Journal of Alternative Agriculture, 15, 26-36. https://doi.org/10.1017/S0889189300008432

[32] Macllvain, T.C. (1921) A Buffer Solution for Colorimetric Comparison. Journal of Biological Chemistry, 49, 183-186.

[33] McCune, B., Grace, J.B. and Urban, D.L. (2002) Analysis of Ecological Communities. MJM Software Design, Gleneden Beach, Oregon.

[34] Yemadje, P.L., Chevallier, T., Guibert, H., Bertrand, I. and Bernoux, M. (2016) Wetting-Drying Cycles Do Not Increase Organic Carbon and Nitrogen Mineralization 
in Soils with Straw Amendment. Geoderma, 304, 68-75. https://doi.org/10.1016/j.geoderma.2016.06.023

[35] Fierer, N. and Schimel, J.P. (2002) Effects of Drying-Rewetting Frequency on Soil Carbon and Nitrogen Transformations. Soil Biology and Biochemistry, 34, 777-787. https://doi.org/10.1016/S0038-0717(02)00007-X

[36] Zhang, B., Yao, S. and Hu, F. (2007) Microbial Biomass Dynamics and Soil Wettability as Affected by the Intensity and Frequency of Wetting and Drying during Straw Decomposition. European of Journal Soil Science, 58, 1482-1492. https://doi.org/10.1111/j.1365-2389.2007.00952.x

[37] Pesaro, M., Nicollier, G., Zeyer, J. and Widmer, F. (2004) Impact of Drying-Rewetting Stress on Microbial Communities and Activities and on Degradation of Two Crop Protection Products. Applied Environmental Microbiology, 70, 2577-2587. https://doi.org/10.1128/AEM.70.5.2577-2587.2004

[38] Chapuis-Lardy, L., Diakhate, S., Djigal, D., Ba, A.O., Dick, R.P., Sembene, P.M. and Masse, D. (2015) Potential of Sahelian Native Shrub Materials to Suppress the Spiral Nematode Helicotylenchus dihystera. Journal of Nematology, 47, 214-217.

[39] Stouffer, D.B. and Bascompte, J. (2011) Compartmentalization Increases Food-Web Persistence. Proceedings of National Academy of Sciences of the United States of America, 108, 3648-3652. https://doi.org/10.1073/pnas.1014353108 